DOI: 10.17707/AgricultForest.62.2.07

\author{
Süleyman AKHAN, \\ Fatma DELIHASAN SONAY, IIhan YANDI ${ }^{1}$
}

\title{
EFFECT OF LONG TERM STARVATION ON SOME PRODUCTIVITY TRAITS AND BODY COMPOSITION OF TURKISH STRAIN BROWN TROUT (SALMO TRUTTA FARIO) WINTERED IN FLOATING NET- CAGES
}

\begin{abstract}
SUMMARY
In this research, brown trout had been wintered for 4 months (Between December 2005 and April 2006) in net-cages in Kuzgun Dam Lake (ErzurumTurkey) without any feeding. Specimens were collected before and after long term fasting in order to investigate effect of starvations on some productivity traits and body composition of fish. Fish were fed daily by commercial trout feed after May 2006. At each sampling time, 15 fish were sampled from square wooden net cages $(5 * 5 * 8 \mathrm{~m})$ for analysis. Research results showed that $66.10 \pm 4.42 \mathrm{~g}$ initial mean weight was decreased to $44.99 \pm 4.40 \mathrm{~g}$ after five months and then fish were recovered and reached to $148.11 \pm 13.00 \mathrm{~g}$ main weight. Similarly, condition factor had been decreased from $1.19 \pm 0.028$ to $0.79 \pm 0.02$ after 5 months and then it was increased as $1.54 \pm 0.053$ fallowing two months. After wintering, carcass yield was increased from $82.86 \pm 0.7 \%$ to $84.16 \pm 1.40 \%$. Long term starvation did not affect raw protein rate statistically before and after wintering. However, raw fat rate was decreased from $2.67 \pm 0.17 \%$ to $1.44 \pm 0.17 \%$ after long term starvation, and then raw fat rate increased up to $3.70 \pm 0.25 \%$ in fallowing months.

Keywords: Brown trout, proximate composition, condition factor, raw protein, raw fat.

\section{INTRODUCTION}

In Turkey, the most cultivated finfish are trout species (besides rainbow trout, brown trout strains and other trout species). Undoubtedly, this high amount of production has been contributed and supported by the reservoir and dam lakes used for production and the net-cage farms be established here. Usually, mainly rainbow trout (O. mykiss) are grown in fish farms established on the dam lakes. Recently other native trout species besides rainbow trout has also started to culture. According to Ministry of Forrest and Water, there are a total 706 dam

\footnotetext{
${ }^{1}$ Süleyman AKHAN, Akdeniz University Faculty of Fisheries, Department of Aquaculture, 7058 Kampüs,Antalya, TURKEY, (corresponding author: akhan@akdeniz.edu.tr), Fatma DELIHASAN SONAY,Recep Tayyip Erdoğan University Faculty of Fisheries, Department of Aquaculture, 53100 Rize, TURKEY, İlhan YANDI, Recep Tayyip Erdoğan University Turgut Kıran Maritime College, 53900 Rize, TURKEY

Notes: The authors declare that they have no conflicts of interest. Authorship Form signed online.
} 
lakes in Turkey. In dam lakes, climate and water temperature determines the production cycle of cage farms. Trout fry $(5-25 \mathrm{~g})$ were stocked in net cages and raised up to $300 \mathrm{~g}$ final weight between September and May (during this period water temperature is below $20{ }^{\circ} \mathrm{C}$ ) in dam lakes which are located on the low altitude. So, summer season is called as dead season in low altitude dam lakes. On the contrary, production season limited between April and November in high altitude lakes such as Kuzgun Dam Lake because of harsh winter and frozen lake surface. Production strategy of high altitude lakes planned as follows. Trout fry (5-10 g) was transferred from hatchery to cage farm in April 2005 and those fry were grown up to 100-250 g until November 2005. And then, grow out trout were $(100-250 \mathrm{~g})$ transferred to sea cages (Black Sea) by the farmer. However, transferring of all raised fish is not profitable during short winter eve due to low demand and price.

Effect of long term cold temperature and lack of feed intake on growth depression and proximate composition of brown trout ( $S$. trutta fario) is unknown. In this research, a group brown trout were restocked in $5 * 5 * 8 \mathrm{~m}$ square net cages and wintered between November 2005 and April 2006. Some of the productivity traits and body composition of wintered fish were monitored and aimed to determine recovery and new harvest time of wintered fish.

\section{MATERIAL AND METHODS}

Research carried out in Dörtmevsim Trout Farm established on Kuzgun Dam Lake (Erzurum, Turkey). Kuzgun Dam Lake which is an irrigation and energy purposeful dam was built in 1997, in district of Erzurum, at $2115 \mathrm{~m}$ altitude. This first private trout fish farm was established on this dam lake. Brown trout $(66.11 \pm 4.43 \mathrm{~g}$ main weight) were stocked in square cages $(5 * 5 * 8 \mathrm{~m})$ in November 2005 and stocked fish had been wintered for 4 months (from November 2005 to April 2006) without any feeding during the winter season. During this period, surface of lake was frozen; however, water surface of floating net cages sometimes was melted until the end of winter. Water temperature and oxygen were measured as $2-4{ }^{\circ} \mathrm{C}, 6-9.5 \mathrm{ppm}$, respectively. After May 2006, water temperature was reached up to $18{ }^{\circ} \mathrm{C}$, and mostly water surface of lake was frozen during this period. When the ice melts on the water surface in April, the fish were begun to be feed routinely. After wintering, samples were collected by monthly (April, May, June) until July 2006. Sampled fish were transferred to Fisheries Faculty Lab (Recep Tayyip Erdoğan University, Rize-Turkey) for checking morphometric data's and proximate quality. Condition factor was calculated as $\mathrm{KF}=\left(\mathrm{W} / \mathrm{L}^{3}\right) * 100$ according to Bagenal (1978). Carcass yield $(\mathrm{CY})$ was calculated according to this formula $(\mathrm{CY}=$ Carcass weight/ Fish weight*100) after gutting fish. Samples were stored at $-18{ }^{\circ} \mathrm{C}$ for proximate analysis. Raw fat, raw protein, raw ash, dry matter and moisture were determined according to AOAC. 


\section{RESULTS AND DISCUSSION}

Research results showed that, initial fish weight had been decreased from $66.11 \pm 4.43 \mathrm{~g}$ to $45.00 \pm 4.40 \mathrm{~g}$ after wintering. After the feeding again, wintered fish recovered old weight and reached to $78.84 \pm 4.88 \mathrm{~g}$ main weight from April to June 2006 (Table 1). Similarly, condition factor decreased dramatically from $1.19 \pm 0.03$ to $0.80 \pm 0.02$ after winter season. Condition factor was recovered as $1.55 \pm 0.05$ after one month. However, carcass yield increased from $82.86 \pm 0.40 \%$ to $84.16 \pm 0.82 \%$ at the end of winter. Effect of long term starvation on proximate composition was showed in Table 2. Initial raw fat rate had been decreased from $2.67 \pm 0.17 \%$ to $1.12 \pm 0.18 \%$ at the end of winter, and raw fat rate was recovered up to $3.71 \pm 0.25 \%$ (Table 2). As a result, wintering fish in dam lake caused significant weight loss in fish (26\% of weight was lost) and lowered condition factor. The fish regains the weight at the end of first month after starting to feed.

Table 1. Changes of some traits in wintering brown trout (Salmo trutta fario) during experiment.

\begin{tabular}{|c|c|c|c|c|c|}
\hline \multicolumn{2}{|c|}{ Sampling Date: } & $\begin{array}{c}2005 \\
\text { November }\end{array}$ & $\begin{array}{c}2006 \\
\text { April }\end{array}$ & $\begin{array}{c}2006 \\
\text { May }\end{array}$ & $\begin{array}{c}2006 \\
\text { June }\end{array}$ \\
\hline Variable & $\mathrm{N}$ & 12 & 14 & 11 & 11 \\
\hline Weight $(\mathrm{g})$ & & $66.11 \pm 4.43^{\mathrm{a}}$ & $45.00 \pm 4.40^{\mathrm{b}}$ & $78.84 \pm 4.88^{\mathrm{a}}$ & $148.11 \pm 13.00^{\mathrm{c}}$ \\
\hline Length (cm) & $17.58 \pm 0.31^{\mathrm{a}}$ & $17.73 \pm 0.54^{\mathrm{ab}}$ & $18.95 \pm 0.18^{\mathrm{ab}}$ & $21.06 \pm 0.66^{\mathrm{b}}$ \\
\hline Condition Factor & $1.19 \pm 0.03^{\mathrm{a}}$ & $0.80 \pm 0.02^{\mathrm{b}}$ & $1.15 \pm 0.05^{\mathrm{a}}$ & $1.55 \pm 0.05^{\mathrm{c}}$ \\
\hline $\begin{array}{c}\text { Carcass Yield } \\
(\%)\end{array}$ & $82.86 \pm 0.40^{\mathrm{a}}$ & $84.16 \pm 0.82^{\mathrm{b}}$ & $75.39 \pm 1.40^{\mathrm{c}}$ & $83.99 \pm 0.45^{\mathrm{b}}$ \\
\hline \multicolumn{6}{|c|}{ Values expressed in the same row with different letter indicate differences are } \\
statistically significant (P<0.05)
\end{tabular}

Table 2. Changes of body composition in wintering brown trout (Salmo trutta fario) during experimental period.

\begin{tabular}{|c|c|c|c|c|c|}
\hline \multicolumn{2}{|l|}{ Sampling time: } & $\begin{array}{c}2005 \\
\text { November }\end{array}$ & 2006 April & 2006 May & 2006 June \\
\hline Variable & $\mathrm{N}$ & 12 & 14 & 11 & 11 \\
\hline Raw protein $(\%)$ & & $18.81 \pm 0.36^{\mathrm{a}}$ & $17.03 \pm 0.58^{\mathrm{b}}$ & $21.82 \pm 1.08^{\mathrm{c}}$ & $20.14 \pm 0.69^{c}$ \\
\hline Raw fat (\%) & & $2.67 \pm 0.17^{\mathrm{a}}$ & $1.12 \pm 0.18^{b}$ & $3.71 \pm 0.25^{\mathrm{c}}$ & $3.02 \pm 0.19^{\mathrm{a}}$ \\
\hline Raw ash (\%) & & $1.22 \pm 0.04^{\mathrm{a}}$ & $1.06 \pm 0.03^{\mathrm{b}}$ & $1.30 \pm 0.02^{\mathrm{c}}$ & $1.31 \pm 0.04^{\mathrm{c}}$ \\
\hline Moisture (\%) & & $74.92 \pm 0.95^{\mathrm{a}}$ & $77.12 \pm 0.55^{\mathrm{b}}$ & $76.31 \pm 0.84^{\mathrm{ab}}$ & $79.56 \pm 0.31^{\mathrm{c}}$ \\
\hline Dry matter (\%) & & $23.15 \pm 0.37^{\mathrm{a}}$ & $23.54 \pm 0.42^{\mathrm{a}}$ & $25.05 \pm 0.39^{b}$ & $22.79 \pm 0.17^{\mathrm{a}}$ \\
\hline
\end{tabular}

In high altitude, feed abundance and feeding of wild fish are depended on climatic conditions. Fish gain condition when the climate and food are available for sustainable life strategy (Gross et al. 1988). In fish, gained lipids and condition are spent for meeting metabolic usage because of low feed intake in cold winter conditions. (Boivin and Power, 1990). Jørgensen et al. (1997) studied 
on seasonal changes of lipid depletion and deposition in Arctic charr. They reported that females and male Arctic charr lost their $80 \%$ and $50-55 \%$ of total lipid reserves respectively during wintering and spawning. In this study, cultivated brown trout raw fat content was reduced from $2.67 \%$ to $1.125 \%$ during wintering and fasting period. Protein content of muscle was also reduced from $\% 18.81 \%$ to $17.03 \%$. Boivin and Pover (1990) reported that muscle and liver lipid and protein reserves of fasted Arctic char (Salvelinus alpinus) decreased during winter season. Zhang et al. (2007) reported that flesh composition of Sparus macrocephalus was affected with 28 day fasting. Muscle fat content was reduced after 3 days later, and protein content was started to decrease on the 14th day.

Our results showed that long term fasted and wintered brown trout were lost weights and condition (Table 1). Growths was also lowered, and mean length was measured as $17.73 \mathrm{~cm}$ after four months. But increased carcass yield was detected. This increase probably caused by empty digestive systems. Thomas et al. (2005) reported slow growth and reduced weight and condition factor in channel catfish which was exposed to cold water and food deprivation.

\section{CONCLUSIONS}

In this study, effects of long term wintering and fasting on some productivity traits and proximate composition of Turkish strain brown trout were investigated. Obtained data showed that four months fasting on cold water conditions (water temperature fluctuated between $2-4{ }^{\circ} \mathrm{C}$ ) caused weight loss and depletion on fat and protein content of fish flesh. However, fish recovered back growth rate and body composition within one month.

\section{ACKNOWLEDGEMENTS}

We wish to thank the farm owner Mr. Huseyin ÇAKMAKÇI and the staff of Dortmevsim Trout Company for their help.

\section{REFERENCES}

AOAC (1990): Offical methods of analysis. 15th ed. Association of Offical Analytical Chemists, Washington DC, 1990.

Boivin, TG. \& Power, G. (1990):Winter condition and proximate composition of anadromous arctic charr (Salvelinus alpinus) in eastern Ungava Bay, QuebecCanadian. Journal of Zoology, 68(11): 2284-2289, DOI:10.1139/z90-319

Bagenal, T. (1978). Methods for assessment of fish production in fresh waters. Blackwell Scientific Publications, Oxford, London, Edingburgh, Melbourne.

Canyurt, M.A. \& Akhan, S. (2009): Development and situation of trout culture in Turkey. Research for Rural Development 2009, Annual 15th International Scientific Conference Proceeding, Jelgava, 90-94.

Gross, M. R., Coleman, R. M. \& McDowall, R. M. (1988). Aquatic productivity and the evolution of diadromous fish migration. Science239,1291-1293.

Jørgensen E.H., Johansen S.J.S., Jobling M. (1997) Seasonal patterns of growth, lipid deposition and lipid depletion in anadromous Arctic charr. Journal of Fish Biology $51: 312-326$. 
Thomas E. Weber T, Brian G. Bosworth (2005) Effects of 28 day exposure to cold temperature or feed restriction on growth, body composition, and expression of genes related to muscle growth and metabolism in channel catfish. Aquaculture 246483 492.

Turkish Ministry of Forestry and Water Affairs, (2014) Formal statistical data for water potential of Turkey. State Hydrulic Works.

Zhang XD, Wu TX, Cai LS, Zhu YF. (2007) Influence of fasting on muscle composition and antioxidant defenses of market-size Sparus macrocephalus. J Zhejiang Univ Sci B. 8(12):906-11. 